\title{
POWER AND AUTHORITY IN MATTHEW'S GOSPEL
}

\begin{abstract}
Besides the strenuous relation of Matthew's community with non-Christian kinfolk, his text also reveals an underlying conflict with Roman Imperial ideology. Herod, Antipas and Pilate specifically impersonate this foreign domination. Apparently these figures have unlimited power which leaves Jesus and his followers as exposed victims. Yet, on the deeper level of the text, Jesus ironically emerges as victor. He represents the Kingdom of God and ironically counters their unfair rule with his authority.
\end{abstract}

\section{INTRODUCTION}

Matthew's text reveals an underlying conflict and struggle for authority (Stanton 1993:26). In Matthean studies, this struggle conventionally was attributed to strenuous Jewish-Christian relations of the first century (e.g. Hummel 1966:55; Keener 1999:46; Repschinski 2000:63ff; Saldarini, 1994:46). This attribution, however, is too limited. Carter (2000:4) argues that Matthew also presents a counter narrative against the Roman Imperial powers. He includes Herod (Matt. 2) and Antipas (Matt. 14) as Roman allies. Vespasian (Matt. 17) and Caesar1 (Matt. 22) are indirectly mentioned in relation to Roman taxes, and Pilate directly in person (Matt. 27) (Carter 2001:35ff.). Apprehensive encounters with the Herod, Antipas and Pilate are explicitly narrated. Matthew's Gospel contests and resists these powers' claims for domination. Basic to the Roman imperial theology was the claim that Rome ruled its empire because the gods have willed Rome to rule the world. The rulers of the Roman Empire were chosen agents of the gods, notably Jupiter's, with the task of

1 The Caesar plays an unseen role in Matthew's narrative, as an "offstage" character (cf. Weaver 2005:111).

Francois $P$ Viljoen, School for Biblical Studies and Ancient Languages, Faculty of Theology, North-west University (Potchefstroom campus). E-mai: viljoen. francois@nwu.ac.za.

Acta Theologica

2011 31(2): 329-345

doi: http://dx.doi.org/10.4314/actat.v31i2.17

ISSN 1015-8758

@ UVIUFS

<http://www.uovs.ac.za/ActaTheologica> 
manifesting the gods' rule, presence, will and blessings in the Empire (Carter 2001:34). Matthew anticipates an alternative community with the coming of God's Kingdom ( $\left.\beta a \sigma \iota \lambda \epsilon i{ }^{\prime} \alpha\right)$ with its authority ( $\left.{ }^{\prime} \xi o v \sigma i ́ \alpha\right)$ over all existing powers (Wengst 1987:46).

In a narrative, the narrator often (wittingly or unwittingly) makes use of techniques to enhance his or her message. The listener somehow has to be able to decipher that technique to grasp the intention of the story. This principle obviously is also applicable to reading the Biblical text. The use of irony is one of such techniques. The basic principle of irony is playing with contrast between appearance and reality. Under the surface level a different reality exists. Making use of irony, Matthew underscores his argument that "something greater" as what the natural eye can perceive, has taken place (Weaver 1996:180). With Jesus a newly proclaimed kingdom has come (France 2008:116). He sets the life of Jesus and his followers within a context of political power. Matthew introduces three imperial figures with titles and attributes of huge authority and power. On the surface level it seems as if Jesus and his followers were totally overwhelmed by the execution of their respective powers. But then Matthew overturns their portraits of power with that of powerlessness.

The intention of this article is to illustrate how Matthew tells that the apparent regime is replaced with something greater. I firstly attend to the authorial audience of the Gospel arguing that the conventionally defined audience is too limited and should include followers of Jesus who are experiencing Roman rule. I then examine three encounters with Roman representatives: the child Jesus' encounter with Herod the king (Matt. 2:123), John the Baptist's encounter with Herod the tetrarch (Matt. 14:1-12) and the adult Jesus' encounter with Pilate the governor (Matt. 27:1-2, 11-38, 54, 62-66; 28:1-15). I indicate how Matthew's narrative mirrors his community's experience of the Roman imperial power.

\section{MATTHEW'S AUTHORIAL AUDIENCE}

When interpreting a text an authorial audience has to be pictured. The authorial audience refers to the audience the author had in mind when writing his text. In Matthean studies the authorial audience was generally depicted as a Jewish-Christian community who had knowledge of Jesus and Biblical traditions, experienced conflict with the synagogue community, and belonged to a minority group (Davies \& Allison 2004:138; Hagner 1996:30; Luz 1998:79; Versteeg 1992:13). Carter (2001:57 ff.) convincingly argues that the audience's experience of Roman imperial rule should be added to the picture of the implied audience. 
Matthew was probably written in Antioch in Syria round about 70AD2. According to Josephus (Jewish Wars 3. 29) Antioch "for extent and wealth unquestionably ranks third amongst the cities of the Roman world". While Rome was the supreme center of power of the Empire, major cities like Antioch extended Rome's political, economic and cultural power throughout the Empire. Antioch was the capital city of the Roman province of Syria and was the base for this province's government (Carter 2001:37).

Matthew's audience was under constant pressure. This put them on the defensive. They became more insistent about their persuasions and selfdefinition. Matthew's plot centers on the question of who is in command (Viljoen 2007:699). While challenging Roman claims he asserts that the world belongs to God. Jesus impersonated the imminence of God's reign. God realizes his kingship in and through Jesus who forms a community by calling them to follow Him. In Matthew's narrative the position of influential figures were constantly threatened by Jesus' authority. The plot evolves around the issue that Jesus had to be removed if their power were to remain intact.

This Gospel was written to confirm Christianity, which entails the kingdom and authority of Jesus as the Messiah. Readers could gain confidence in the trustworthiness of their faith. This led to a number of distinctive emphases in this Gospel. The one which is particularly relevant for this article is the emphasis on the kingdom of God and the authoritative position of Jesus and his teaching. On several occasions in the narrative his authority is claimed and demonstrated. Three times in the Gospel Jesus is said to present God's presence: "They will call Him 'Emmanuel', which means 'God with us' $(\mu \in \theta$ ' $\dot{\eta} \mu \omega \hat{\nu}$ o $\theta \in o ́ s$ )" (Matt. 1:23); where two or three come together in my name, there I am with them" (Matt. 18:20); and "I am with your always" (Matt. 28:20). These announcements counter Roman claims that the Caesar was the agent of Jupiter and the present deity (deus praesens) (Statius, Silvae 5.2.170). Jesus is the beloved Son of God (Matt. 3:17 and 17:5). Jesus teaches his disciples to speak of and pray for the "Kingdom" ( $\left.\beta a \sigma \iota \lambda \in \epsilon^{\prime} \alpha\right)$ of God (e.g. Matt. $6: 10)$. The crowds were amazed at his teaching "because He taught with authority ( $\epsilon^{\prime} \xi_{0}$ ov $\left.\sigma^{\prime} \alpha\right)$ and not as their teachers of the law" (Matt. 7:29). When his actions of forgiving the sins and healing of a paralytic were questioned by teachers of the law, Jesus declared that $\mathrm{He}$ as Son of Man had the authority on earth to forgive sins (Matt. 9:6). The crowds were filled with awe because God had given such authority to men (Matt. 9:8). He gave authority to his disciples to drive out evil spirits and to cure every kind of disease and sickness (Matt. 10:1). Jesus claimed that "one greater than the temple is here" (Matt. 12:6), "someone greater than Jonah" (Matt. 12:41), and "someone greater

2 Most scholars opt for the origin of the Gospel in Antioch in Syria. This view can be traced back to the classic proposal of Streeter for the case of an origin in Antioch (Streeter 1924:500-527). See also Keener (1999:41 f.) and Stanton (1985:1942). 
than Solomon" (Matt. 12:42). Yet his authority is questioned and his claim to this fiercely criticized by the chief priests and the elders (Matt. 21:23-27). This emphasis finds its ultimate expression in the Great Commission where Jesus proclaims: "All authority ( $\left.\pi \hat{\alpha} \sigma \alpha \mathcal{C}^{\epsilon} \xi o v \sigma i ́ a\right)$ in heaven and earth has been given to me" (Matt. 28:18). Heaven and earth signify all creation over which God claims to exercise sovereign rule through Jesus. Jesus therefore commands his disciples with the Great Commission giving them authority of making disciples by baptizing and teaching all nations.

\section{HEROD THE KING AND JESUS THE NEW BORN KING}

In the first scene to be investigated, Matthew compares Herod with Jesus ${ }^{3}$. Jesus' birth is presented as a threat to Herod, the vassal king of the Romans, who acknowledged Rome as "masters of the world" (Josephus, Antiquities, 15.387). Matthew introduces Herod and Jesus each as a king ( $\beta a \sigma \iota \lambda \in u ́ s)$ by way of contrast: "After Jesus was born in Bethlehem in Judea, during the time of King ( $\left.\beta a \sigma \iota \lambda \in u_{S}\right)$ Herod $^{4}$, Magi from the east came to Jerusalem and asked, 'Where is the one who has been born king ( $\left.\beta a \sigma \iota \lambda \epsilon v_{S}\right)$ of the Jews? We saw his star in the east and have come to worship him"' (Matt. 2:1-2). The magi come from the east, the location of Rome's enemy Parthia. Not surprisingly, they do not recognize Rome's puppet king, Herod. Their question was highly non-diplomatic revering Jesus' position of king above that of Herod's. This puts the magi in their conventional role as posing a threat to ruling powers. This juxtaposition is so frightening to Herod that he seeks to kill Jesus (Carter 2001:62).

At first the reference to King Herod appears to merely be a historical reference to date the birth of Jesus. However the text that immediately follows, puts the powerful Herod in an ironical position. Beare (1981:77) comments:

If (Matthew) mentions Herod, it is not for the sake of dating, but that he may serve as the false king who trembles at the thought of the coming true king and resorts to desperate measures to eliminate him as a threat to his power.

Matthew introduces Herod as the king (of Judea) and then immediately subverts his position by characterizing Jesus the new born king of the Jews who is worthy to be worshipped (Patte 1987:33). Matthew poses two opposing levels of reality. On the surface level Herod apparently is the king (over Judea),

3 The story forms part of Matthean Sondergut.

4 At this time both Galilee and Judea were under the same political administration. Herod was king of the Jews, not only of Judea. 
but on the deeper level of true reality Jesus is the king of the Jews (Weaver 1996:182). Matthew consistently portrays Herod as a character with enormous power. He is introduced in his role as "king" (Matt. 2:1). He is depicted as a person with enormous political influence. Matthew reflects this as the birth of Jesus is dated in relation to him: "Jesus was born in Bethlehem in Judea, during the time of King Herod" (Matt. 2:1). Horsley (1993:29) remarks: "the story in Matthew 2 comes to life vividly against the background of Herodian exploitation and tyranny". Herod's title reappears with reference to him, "King Herod" (Matt. 2:3) and "the king" (Matt. 2:9). King Herod's rule was that of a typical despot ${ }^{5}$. He governed with fear, deceit and murder. He was named king of Judea by the Roman Senate in 40 BC. By 37 BC he had crushed, with the help of Roman forces, all opposition to his rule. Several incidents involved the execution of large numbers of persons. In his last years he became increasingly suspicious of any threat to his position. His life was dominated by the obsessive defense of his throne. In fits of distrust and jealousy he even killed people directly related to him like his brother-in-law (Antiquities 15. 53-55), mother-in-law (Antiquities, 15. 247-251) and even his wife Mariamne (Antiquities 15. 222-236). In his final years his three oldest sons were also killed on suspicion of plotting to seize their father's throne (Antiquities 16. 392-394 and 17. 182-187) (cf. Carson 1984:86; France 2007:84-85; Senior 1998:44).

Matthew mentions the impact Herod's personal feelings had on all Jerusalem": "When King Herod heard this he was disturbed, and all Jerusalem with him" (Matt. 2:3). This was

not because most of the people would have been sorry to see Herod replaced or because they were reluctant to see the coming of King Messiah, but because they well knew that any question like the Magi's would result in more cruelty from the ailing Herod (Carson, 1984:86).

It was in character of a person as obsessive as Herod to spare nothing to eliminate any suspected dynastic rival.

Herod's concern about a potential rival, led him to summon the experts: "When he had called together all the people's chief priests and teachers of the law, he asked them ..." (Matt. 2:4). Though the relation between Herod and the Sanhedrin was not cordial, he had the power to summon them. They answered his questions: "In Bethlehem in Judea,' they replied, 'for this is what the prophet has written"' (Matt. 2:5-6). Likewise Herod had the power to call

5 Josephus (Antiquities books 14-18) is currently the most comprehensive source of what we know about Herod and his rule.

6 In Matthew Jerusalem also represents the political power which Jesus would eventually challenge (cf. France 2008:114). 
up the gentile dignitaries, "Then Herod called the Magi" (Matt 2:7), and they reported to him. The Magi initially obeyed the commands Herod had given them: "He sent them to Bethlehem and said, 'Go and make a careful search for the child. As soon as you find him, report to me, so that I too may go and worship him.' After they had heard the king, they went on their way" (Matt. 2:89). Herod concealed his deceitful and murderous intention as he manipulated the situation.

Matthew then tells of God's intervention by dream visions to the Magi and Joseph respectively to save the new born king. This left Herod furious which incited him to order the infanticide: "When Herod realized that he had been outwitted by the Magi, he was furious, and he gave orders to kill all the boys in Bethlehem and its vicinity who were two years old and under" (Matt. 2:16-18). In his frustrated rage, and not being able to specifically identify his potential rivalry, he ordered the indiscriminate killing of all male infants in the area. His subservients executed this gruesome demand without any indication of hesitation ${ }^{7}$. Herod acts deceptively and ruthless to carry out his evil intentions - all of this in an effort to maintain his powerful position. His authority is based on terror. He both possesses and exercises the power of life and death over his subjects.

The portrayal of Jesus is done in strong contrast with that of Herod. He is presented as the counter king: "the one who has been born king of the Jews" (Matt. 2:2), "the Christ" (Matt. 2:4), "a ruler who will be the shepherd of my people Israel" (Matt. 2:6) and "my Son" (Matt. 2:15). This King is not to be found in the capital Jerusalem, the city of atrocious king Herod and the deceiving Jewish religious leaders, but in the lowly Bethlehem, the city of David (Matt. 2:5-6). To emphasize the lowliness of Bethlehem, Matthew makes use of a fulfillment quotation from Micah $5: 2^{8}$. Along with the designator of Jesus as king of the Jews, another term is prominently used. Throughout the narrative

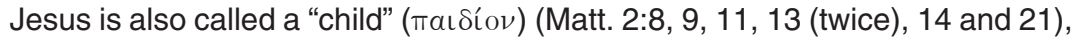
which becomes a fixed formula ${ }^{9}$. This formula clearly implies the helplessness and dependence of Jesus, which stands in strong contrast with the portrayal of the brutal Herod. On the surface level Jesus appears to be powerless while Herod is portrayed as the powerful.

While presenting the utter power of Herod and the helplessness of Jesus on the surface level, Matthew immediately presents a different reality on the

7 This story of the rescue of this new born king clearly resembles Pharaoh's unsuccessful attempt to kill Moses (cf. France 2007:83).

8 Where Micah described Bethlehem as "small" the LXX went further and made it "smallest".

9 Legends of threats to royal children were fairly common in ancient literature (Luz 1998:144). 
deeper level. As noted above he begins the story by contrasting the positions of "Herod the king" with that of Jesus "who has been born king of the Jews" (Matt. 2:2). Matthew continues to tell that "King Herod" was disturbed (even terrified) at the news of a new born king of the Jews" (Matt. 2:3). The reader realizes that Herod's position as "king of Judea" is being challenged by "the king of the Jews". For the magi as foreign dignitaries to prostrate ${ }^{10}$ themselves in homage before a child in an ordinary house illustrates the sharp reversal of power. The decline of Herod's position is further stated when he realizes that he had been outwitted by the Magi. His pathetic position is ironically presented as being the one who tried to deceive the Magi with his presumption to worship Jesus himself. Herod lost his power to deceive people in order to attain his evil purposes and simultaneously became powerless to prevent himself of being deceived ${ }^{11}$.

Matthew repeatedly explains the reasons for Herod's failure. Prior interventions by the angel of the Lord defeated the evil plans of Herod. Before Herod could get report from the Magi about the location of Jesus, the angel of the Lord instructed them not to return to Herod to tell him where to find the child (Matt. 2:12). Before Herod could send his henchmen to kill the child, the angel instructed Joseph to flee to Egypt (Matt. 2:13-14). The angel warned Joseph to remain in Egypt as long as Herod was capable of hunting the child (Matt. 2:20). Only when Herod was dead ${ }^{12}$ and no longer a threat to the child, did the angel instruct Joseph to return to Israel. Before Herod's son had any opportunity to carry out the evil intention of his father the angel warned Joseph to settle in Galilee rather than in Judea (Matt. 2:22-23). As the story unfolds the reader is repeatedly reminded that Jerusalem remained hostile territory for the new king of the Jews, and Bethlehem was too close for comfort. God carefully directed the events by supernatural interventions. Matthew emphasizes that the genuine power lies with God and not with evil kings. Neither Herod nor his son had ultimate control over these events. Matthew underscores this fact with a series of fulfillment citations. Gibbs (2006:135) remarks: "The son is the one who fulfills Scripture".

With irony the narrative refers three times to Herod's death (Matt. 2:15, 19 and 20). The ironical confirmation of the fact is underlined when Herod the king, who's primary aim throughout the narrative it was to kill the child, himself was dead while the intended victim was well and alive. This sharp contrast

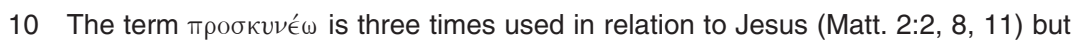
not for Herod.

11 According to Josephus Herod's later life was dominated by his obsessive defense of his throne (Antiquities of the Jews 15-17).

12 Ex. 4:19: "all the men who had wanted to kill you, are dead" is echoed in Matt. 2:20. As Moses had escaped the infanticide of Pharaoh, and as adult fled the Pharaoh's anger, so did Jesus escape the onslaught of Herod. 
is stated in the words of the angel: "... for those who were trying to take the child's life are dead (Matt. 2:20). "For the readers of the Gospel, there is no doubt about who has the power of life and death over Herod: it is God" (Patte 1987:36).

'Kings of the earth' (cf. Ps. 2:1-3) like Herod and the Pharaoh whom he resembles, always resist God's sovereignty, but God laughs them into oblivion (Matt. 2:4) (Carter 2001:62).

Matthew clearly states that Herod was not the genuine king over Judea and he did not hold the actual power. Instead Jesus as new born king of the Jews held the power. True power belonged to the vulnerable child and not to the terrifying despot. Patte (1987:37) aptly remarks: "true authority, divine authority, is not based on the use (or the threat of use) of power". The narrative works on two levels. Herod and his tirades are the surface events that drove the plot. But the dream oracles and the formula quotations reveal another (Senior 1998:50). Jesus is later to be hailed as the king who is entering Jerusalem (Matt. 21:5).

\section{HEROD THE TETRARCH AND JOHN THE BAPTIST}

Later in his narrative Matthew introduces another influential political character, Herod the tetrarch ${ }^{13}$ (Matt. 14:1-12). This Herod appears shortly after the news of Jesus' ministry of power had spread through Galilee: "At that time Herod the tetrarch heard the reports about Jesus, and he said to his attendants, 'This is John the Baptist; he has risen from the dead! That is why miraculous powers are at work in him"' (Matt. 14:1-2). Though it is the ministry of Jesus that prompts the reaction of Herod, John the Baptist serves as the counterpart to Herod's power.

On the surface level Matthew portrays Herod the tetrarch as a person with considerable power (Weaver 1996:187). He is introduced as "the tetrarch" (Matt. 14:1), and later identified as "the king" (Matt. 14:9), a title that was never officially approved for him, but was popularly used to flatter him (France 2007:553) ${ }^{14}$. He had servants (Matt. 14:1). He had the authority to arrest John, to bind him and put him in prison (Matt. 14:3). He probably did this because of the public influence of John who criticized him as the tetrarch for taking

13 The Herod of this story is Herod Antipas, tetrarch of Galilee and Perea from 4 BC to AD 39 (France, 2007:553).

14 Matthew describes this Herod as tetrarch not as king, though in verse 9 uses it ironically. This is a title Herod Antipas aspired and campaigned for. His father officially carried the title "king". 
his brother's wife ${ }^{15}$. Herod had the means to have luscious and extravagant parties (Matt. 14:6) ${ }^{16}$. According to Josephus (Antiquities 18. 102) Antipas had a reputation for his excessive parties. During one of such parties he exercised the power to promise with an oath to give the daughter of Herodias whatever she would ask (Matt. 14:7). His servants would carry out his coldblooded order to behead John in the prison (Matt. 14:9-10). Matthew emphasizes that Herod had the ultimate power of life and death over his subordinates. Just as Herod the king before him, Herod the tetrarch exercised power for selfish and evil purposes. He did not care whom he had to kill and how gruesome his actions might have been.

In contrast to Herod the tetrarch's power, John the Baptist is pictured as powerless and pitiful. John was arrested, bound and put in prison (Matt. 14:3). He became the victim of Herodias' evil suggestion and the daughter's ruthless demand for the head of John on a platter (Matt. 14:8). Eventually John was beheaded by order of Herod (Matt. 14:10) and his head was served on a platter (Matt. 14:11). On the surface level the contrast between the power of Herod the tetrarch and the defenselessness of John the Baptist can hardly be put stronger.

On the deeper level the balance of power is severely tilted. This shift of power is presented in the opening verses of the story. Herod is introduced as highly superstitious and terrified. The idea of a ghostly or even physical return of someone who has had a special influence and whose influence had been stopped by violent death, formed part of popular superstition (France 2007:553 $)^{17}$. Herod feared the powers of John as a man raised from the dead, because Herod himself had ordered John to be killed (Matt. 14:1-2). While Herod had the power over life and death, he ironically feared the man he had ordered to be killed! Herod thought that the man he had executed now had powers even greater than before as miraculous powers were to be expected of such a supernatural figure. In addition to this the reader realizes that the object of Herod's fear (John the Baptist who had be raised from the dead), was a product of his own bad conscience.

As the story unfolds, the reader becomes aware that Herod's actions constantly were motivated by his fear for others. He feared John the Baptist

15 Josephus (Antiquities of the Jews 18. 109-15) explicitly mentions the political implications of Herod's marriage with Herodias. It was publically regarded as an irregular action which inter alia provoked a rivalry with his former father-in-law, the Nebatean king of Petra.

16 Matthew has reduced many of Mark's vivid details about the celebrations (Mark 6:14-29), although his account still portrays the court as cruel and exploitive.

17 Josephus (War, 1. 599) describes the appearance in Herod's palace of the ghosts of his murdered sons Alexander and Aristobulus. 
(Matt. 14:3) and the crowd (Matt. 14:5). He was manipulated by his wife Herodias and her daughter (Matt. 14:9-11) and feared that he would lose face with his party guests after his frivolous public oath (Matt. 14:9-11). As a result Herod could not carry out his own will. When he himself wanted to get rid of John, his fear of the crowds prevented him. When he wished to keep John alive his fear of the crowds once again prevented him to do so. Because of his thoughtless promise to offer Herodias' daughter whatever she wished, he was forced to act against his own will. He faced a political dilemma, as he officially had no right to impose the death penalty. John's beheading would become a public infringement of the law, which made his position extremely vulnerable (Keener 1999:401). Herodias comes out as the dominant personality which must have been extremely humiliating in Herod's social context ${ }^{18}$. Weaver (1996:190) vividly defines Herod's weak position:

In spite of his apparent power, Herod effectively is a puppet on a string, operated now by this outside force and now by that one.

Ironically the apparent defenseless John the Baptist demonstrates real power. Although Herod arrested John and wanted to eliminate him, he could not, as John enjoyed public support. His ministry was so powerful that he had been recognized as a "prophet" (Matt. 14:5). In a face to face encounter he sharply condemned Herod's marital relationship with Herodias, the wife of his brother Philip (Matt. 14:4). The power of John actually subordinated Herod. Herod feared John so much that he ordered John to be imprisoned, as John's objection to the marriage of Antipas and Herodias would have had wide popular support amongst the more conservative Jewish subjects ${ }^{19}$ (cf. France, 2007:554). The ultimate irony lies in the outcome of these series of events. While Herod thought that he got rid of his rival by putting John to death, he found himself believing that John was raised from the dead (Matt. 14:2) and had even greater powers as the John he had executed.

It is striking that this pompous scene of Herod's feast with its tragic outcome is followed by the simplicity of the wholesome feast during which Jesus fed the crowd with five loaves and two fish that follows in Matt. 14:13-21. This depicts the contrast between Herod's unjust detrimental empire and the beneficial Kingdom of God.

18 Josephus (Antiquities, 18. 240-246) accounts the ruthless ability of Herodias to manipulate Antipas. It may well be that her daughter's dance was designed from the beginning to undermine Antipas's defenses (France, 2007:556).

19 Antipas's supposed Jewishness was extremely vulnerable amongst the Jews, as his father was a Idumean and his mother Samaritan. Herod's ritual status was also in question as Lev. 20:21 describes the marriage with a brother's wife as impurity (Webb 1991:366). 
Matthew clearly demonstrates that the power of Herod in actual fact was impotence in comparison with the power of God.

\section{PILATE THE GOVERNOR AND JESUS THE ACCUSED}

More than was the case with King Herod and Herod the tetrarch Matthew portrays Pilate as a man with tremendous power. He is introduced as the governor (i $\gamma \in \mu(\hat{\omega} \nu)$. The importance of the term "governor" is highlighted by its sevenfold use through the scene (Matt. 27:2, 11 (twice), 14, 15, 21; 28:14). This commonly used term for governors attests the significance of Rome's presence in the person of Pilate. As Roman provincial governor of Judea ${ }^{20}$ he held judicial power of this province which stood under Roman control ${ }^{21}$. He probably had come to Jerusalem during the Passover to exercise control over the feast (Senior 1998:320). For the inhabitants of provinces of Rome, the governor was the most visible face of the Roman occupation and the most powerful human symbol of Roman Empire and domination (Weaver 2005:112).

The power to decide on a capital punishment vested in the governor. The characters around Pilate appeal to Pilate as the person with real authority to grant their requests. The chief priests and elders lay charges against Jesus before Pilate (Matt. 27:12-13). Studies of the structure of aristocratic societies and Roman imperial strategies illuminate this handing over of Jesus to Pilate. It was the transfer of Jesus as a lower status person (one of the humiliores) from the religious leaders as one part of the ruling elite (the honestiores) to another and more important part of it (Carter 2001:150). Roman justice demonstrated a profound bias in favour of the elite and against those of lower class. Part of Rome's strategy for societal control was to secure cooperation of the local elite. Pilate's role as governor in this scene was to protect and advance Rome's interests in alliance with the local elite. It was therefore highly unlikely that Pilate would do anything that could infringe his relation with this local elite. As one of the humiliores and with no political power, Jesus had very little chance of being released 22 .

20 Pilate served as governor of Judea from 26 to 36 AD.

21 The Gospel author assumes that his audience has experience of a Roman governor because they lived in a world where such governors were familiar figures. Antioch was the residence of the governor of Syria.

22 This incident should remind the reader of Jesus' previous warning to his disciples: "Be on your guard against men; they will hand you over to the local councils and flog you in their synagogues. On my account you will be brought before governors (i $\gamma \in \mu(\omega) \nu)$ and kings" (Matt. 10:17-18). 
As Roman governor he had this (biased) power of life and death over his subjects, whether they were Jewish or Roman. He had the authority to release a prisoner chosen by the crowd (Matt. 27:15). He took seat on the judge's seat $(\beta \eta \dot{\mu} \alpha)^{23}$ in order to pass judgment (Matt. 27:19) ${ }^{24}$. At the word of the governor the soldiers took Jesus to Golgotha and crucified Him along with other criminals (Matt. 27:31-38). Later the chief priests and Pharisees requested Pilate to secure the tomb where Jesus' body has been buried (Matt.

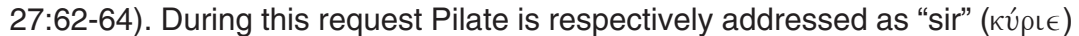
(Matt. 27:63). The chief priests and Pharisees assure the Roman soldiers that they will keep them out of trouble should Pilate become aware of their cover up story about the body of Jesus.

In contrast to Pilate, Jesus is presented as powerless. Jesus as "king" is solemnly rejected by the Jewish leaders and the crowds under their influence. Jesus' vulnerability is portrayed in three consecutive episodes; the unjust accusations against Him, the choice between Him and Barabbas ${ }^{25}$, and the mockery and execution He had to endure. His opponents planned to put Him to death (Matt. 27:1). In the first scene the religious leaders bound Jesus, led Him away and turned Him over to Pilate (Matt. 27:2, 18, 26). He was accused by chief priests and elders (Matt. 27:12-13). He had to suffer the mockery of the Sanhedrin. For them to put the title "king of the Jews" in the mouth of the Galilean Jesus was extremely sarcastic. As accused Jesus was interrogated by Pilate (Matt. 27:11-13). To the first ironic question ${ }^{26}$ of Pilate Jesus only responded with an enigmatic reply: "Yes, it is as you say" (Matt. 27:11). When Pilate again asked Him to respond to the cascade of accusations, Jesus offered no response, to the great amazement of the governor (Matt. 27:14). Roman law presumed that the lack of a defense meant guilty as charged (Stanton 1993:160). Jesus admitted his "guilt". He is King of the Jews. Matthew underscores the silence of Jesus. With this, Matthew probably wanted to evoke the image of the suffering servant who stood silent

23 This seat was probably a raised platform in front of the governor's residence from where he officially and authoritatively could act from.

24 Jesus stands before the seated governor, an ironical reversal of the destined position of Jesus as judge of the world (Matt. 25:31) (France 2007:1051).

25 France (2007:1054) poses the likely possibility the Barabbas was not an ordinary criminal, but a freedom fighter. To the Romans he would have been a revolutionary, but for the Jews a patriotic folk hero. Matthew's adjective "well known" (Matt. 27:16) would then have had either positive or negative connotations, depending on who is speaking. The question for the Jews would then be what kind of redeemer they were interested in, a politic rioter or the Messiah Jesus had proposed to be (France 2008:121). The presence of such a rebel would lend further color to the accusation the Jesus of Nazareth was claiming to be the "king of the Jews".

26 The question "Are you the king of the Jews?" is clearly ironical when asked be the man who held the political authority over Judea. 
before his accusers (Isa. 53:7) and whose bearing caused kings to be amazed (Isa. 52:14-15). Jesus' vulnerability and humiliation is further described when a choice is made between Him and Barnabas, the notorious prisoner. Seemingly Jesus' fate would be decided by the unfair choice of the crowds (Matt. 27:17). The chief priests and elders persuaded the crowd to ask Pilate to have Jesus executed (Matt. 27:20) as they were not only pro-Barnabas, but expressly anti-Jesus. The repeated demand for crucifixion by a Jewish crowd was unusual as crucifixion was regarded as an alien and barbaric act only familiar as a Roman punishment (France, 2007:1056). Jesus was handed over to be flogged and crucified (Matt. 17:26). After being stripped (Matt. 27:28), He was enrobed with a scarlet cloak. The word for "cloak" here is specifically used for a standard military cloak and colored with cheap red ${ }^{27}$ dye, which intensifies the irony. The humiliation of Jesus escalated from mock homage (crowning with thorns, the reed scepter, kneeling before Him and hailing Him as king ${ }^{28}$ ) to physical abuse (spitting and beating Him) (Matt. 27:28-31). After this deep humiliation, He was finally dishonored by being crucified, and ironically, with the accusation scornfully fixed above his head: "Jesus the King of the Jews" (Matt. 27:27). There He was left hanging on a scandalous Roman cross (Matt. 27:37). On the surface level Jesus is starkly depicted as the biggest disgrace. These scenes demonstrate the supposed triumph of the unjust rule.

Obviously, the message of Matthew lies on a deeper level. On this level the powerful Pilate is exposed as a powerless puppet (Weaver 2005:116). He had to act upon the wish of the crowds (Matt. 27:15, 17, 21). The weakness of Pilate is depicted when the crowds starts off enquiring him but ends up shouting all the loader to him (Matt. 27:23) which led to a public uproar he could not control (Matt. 27:24). He realized that the Jewish leaders' desire to get rid of Jesus, did not stem from concern for the Roman law, but from their own religio-political self-interest (Matt. 27:18). The intervention of Pilate's wife deepens the foolishness of the accusations of the Jewish leaders: even a gentile woman could see that Jesus was innocent, as she knew this from a dream oracle ${ }^{29}$. The final futile attempt of Pilate to calm the crowds, "What crime has He committed" (Matt. 27:23) is drenched in irony. Jesus in Matthew is the embodiment of justice. Even with this attempt Pilate is unable to influence the views which he knew was wrong. Pilate himself realized his weakness when he saw that he was getting nowhere (Matt. 27:24). Pilate is left to capitulate to the unfair accusations. This powerful man is powerless to do what he knows would be right and complies with their wishes.

27 Mark 15:17 refers to a purple robe, the color of royalty. Matthew's "scarlet" intensifies the irony of the scene.

28 "Hail, King of the Jews!" parodies the formal imperial greeting: "Ave, Caesar!"

29 Dreams were commonly regarded as means of divine guidance. Matthew also recalls the Magi and Joseph to be guided by dreams (Matt. 1:20; 2:12, 13, 19, 22). 
"Pilate, though he has all of Rome behind him and though he knows Jesus to be guiltless, nevertheless fears a riot brewing and thus, to keep the peace, determines that Jesus' life is expendable (Goldberg 1985:190).

Pilate has been manipulated into executing the scam of the religious leaders (Matt. 27:1-20). Later he again is being manipulated to spread the story that Jesus remained dead in the public perception (Matt. 28:12-15).

Matthew expects his readers to realize the irony in the accusations and honors heaped upon Jesus in gestures of mockery. While publically stripped of all honour and power, $\mathrm{He}$ is in reality is the King of the Jews, the temple builder, the Savior, the Son of God. The drama of the earthquake, the tearing of the temple curtain, and many holy people who had died being raised to life, would tell of the world-changing significance of these events (Matt. 27:51-53). Even the tough soldiers who recently knelt in ridicule before the disgraced "King of the Jews" would realize that He was the Son of God (Matt. 27:54). The title "son of God" was particularly associated with the emperor Augustus and his successors (Statius Silvae 4.2.14-15). In using this title for Jesus, the soldiers transferred to Jesus a title that belonged to emperors like Augustus (Stanton 1993:69).

The ultimate irony appears when the powerless Jesus had risen from the dead (Matt. 28:1-10). While the imperial system had the power to inflict death, God's power and presence are not restricted, but overcome that death. Jesus' resurrection strips Pilate, the religious leaders and the crowds of all their malicious power. The powerful position of Pilate as the governor $(\dot{\eta} \gamma \epsilon \mu \dot{\omega} \nu)$ is replaced by Jesus, "the ruler (írov́ $\mu \in v o s$ ) who will be the shepherd ${ }^{30}$ of my people of Israel" (Matt. 2:6). The description of Pilate the governor and Jesus as governor represent fundamentally two contrasting empires. The one represents the Roman emperor and empire, and the other proclaims and embodies God's empire. The appearance of the angel underscores God's power. His appearance is accompanied by a violent earthquake, and the guards were terrified. The evil empire could not succeed to remove Jesus' presence of God (Carter 2001:67). The risen Jesus has received "all authority in heaven and on earth" (Matt. 28:18) He is present with his disciples "to the ends of the age" (Matt. 28:20). The infinitely greater power of God diminishes the pretentious power of the evil empire.

30 The image of "shepherd" is commonly used for rulers in the Biblical text (Jer. 23:14; Ezek. 34:5-6). 


\section{CONCLUSION}

When reading Matthew, one should also be conscious of the experience of Roman rule by the authorial audience. Matthew addresses their concern by ironically telling about encounters with three representatives of the Roman Empire. He assures his audience that God exercises sovereign rule over all creation. His Kingdom is not fully acknowledged yet and the current society is thus not ordered according to God's purposes. That is why their world is miserably unjust. Matthew presents by way of a counter narrative a theological challenge by contesting the worldview that claimed that the world belonged to Rome and its Empire. Jesus is the agent of God's rule. He demonstrates God's imminent Kingdom. He attests God's sovereignty and anticipates its final establishment over all. The Gospel teaches an alternative understanding of the world.

Jesus' followers live in the imperial world that crucified Him. On the surface level God's Kingdom is diminished, but this did not reflect the true reality. Matthew portrays the hollowness of the agents of the Roman Empire by contrasting them with the authority of Jesus, the Son of God. When confronted by his authority their influence proves to become void. "This perspective on the real world is what will empower the believers of the Matthean church for their inevitable encounters with the "Herod's" and "Pilate's" of their own day, the "governors and kings" before whom they will be called to bear witness to their faith" (Weaver 1996:196). They must not be discouraged as "something greater" than what the natural eye can see, has come. Matthew anticipates the coming triumph of God's Kingdom over all things.

\section{BIBLIOGRAPHY}

BEARE, F.W.

1981. The Gospel according to Matthew. San Francisco: Harper \& Row.

Carson, D.A.

1984. Matthew. The Expositor's Bible Commentary, vol. 8. Grand Rapids: Zondervan.

CARTER, W. 2000. Matthew and the margins. A Socio-Political and Religious reading. Sheffield: Sheffield Academic Press. (Journal for the Study of the New Testament Supplement Series, 204).

2001. Matthew and empire. Initial explorations. Harrisburg: Trinity Press International. 
Davies, W.D. \& Allison, D.C. 2004. Matthew 1-7. Volume 1. International Critical Commentary. London \& New York: T \& T Clark.

France, R.T.

2007. The Gospel of Matthew. Michigan \& Cambridge: Eerdmans.

2008. Matthew and Jerusalem. In: D.M. Gurtner \& J. Nolland (eds.), Built upon the Rock. Studies in the Gospel of Matthew (Grand Rapids \& Cambridge: Eerdmans), pp. 108-127.

GiBBS, J.A.

2006. Matthew 1:1-11:1. Concordia Commentary; a Theological exposition of the Sacred Scripture. Saint Louis: Concordia.

GoldBerg, M.

1985. Jews and Christians, getting our stories straight: The exodus and the passionresurrection. Nashville: Abingdon.

HAGNER, D.

1996. The Sitz in Leben of the Gospel of Matthew. In: D.R. Bauer \& M.A. Powell (eds.), Treasures new and old. Contributions to Matthean studies (Atlanta: Scholars Press), pp. 27-68.

HORSLEY, R.A.

1993. The liberation of Christmas: The infancy narratives in social context. New York: Continuum.

Hummel, R.

1966. Die Auseinandersetzung zwischen Kirche und Judentum im Matthäusevangelium. München: Kaisar.

JosepHUS.

Antiquities of the Jews. Jewish wars.

KeEner, C.S.

1999. A commentary on the Gospel of Matthew. Grand Rapids: Eerdmans.

LUZ, U.

1998. Matthew 1-7: A continental commentary. Minneapolis: Augsburg Fortress.

PATte, D.

1987. The Gospel according to Matthew: a structural commentary on Matthew's faith. Philadelphia: Fortress.

RepschinsKI, B.

2000. The controversy stories in the Gospel of Matthew: Their redaction, form and relevance for the relationship between the Matthean community and formative Judaism. Göttingen: Vandenhoeck \& Ruprecht. 
SENIOR, D.

1998. Matthew. Abingdon New Testament commentaries. Nashville: Abingdon.

SALDARINI, A.J.

1994. Matthew's Christian-Jewish Community. Chicago \& London: University of Chicago.

Stanton, G.N.

1985. The origin and purpose of Matthew's Gospel. Matthean scholarship from 1945 to 1980. In: H. Temporini, \& W. Haase (eds.), Aufstieg und Niedergang de römischen Welt, Teil II, Band 25, Teilband 3 (Berlin: De Gruyter), pp. 1889-1951.

1993. A gospel for a new people: Studies in Matthew. Edinburgh: T \& T Clark.

StREETER, B.H.

1924. The four Gospels. London: University Press.

Versteeg, J.

1992. Evangelie in viervoud. Een karakteristiek van de vier evangeliën. Kampen: Kok.

VILJOEN, F.P.

2007. Matthew, the church and anti-Semitism. Verbum et Ecclesia 28(2):698-718.

WEAVER, D.J.

1996. Power and powerlessness: Matthew's use of irony in the portrayal of political leaders. In: D.R. Bauer and M.A. Powell (eds.), Treasures new and old. Contributions to Matthean studies (Atlanta: Scholars Press), pp. 179-196.

2005. Thus you will know them by their fruits. In: J. Riches \& D.C. Sim (eds.), The Gospel of Matthew in Roman Imperial context. (London \& New York: T \& T Clark), pp. 107-127.

Wengst, K.

1987. Pax Romana and the peace of Jesus Christ. Philadelphia: Fortress.

WebB, R.L.

1991. John the baptizer and prophet: a Socio-Historical Study. Sheffield: Sheffield Academic Press.

Keywords

Authority

Power

Authorial audience

Irony

Matthean community
Trefwoorde

Gesag

Mag

Outeursgehoor

Ironie

Matteusgemeenskap 